\title{
特集 燃料電池用高分子膜の最前線
}

\section{炭化水素系高分子電解質膜の可能性と問題点 陸川政弘}

\author{
上智大学理工学部化学科％102-8554 東京都千代田区紀尾井町7-1
}

\section{Possibility and Problems for Polymer Electrolytes Based on Hydrocarbon Polymers}

\author{
Masahiro Rikukawa \\ Department of Chemistry, Sophia University, 7-1 Kioi-cho, Chiyoda-ku, Tokyo 102-8554, Japan
}

This paper presents an overview of the possibility and problems of new proton-conducting polymer electrolyte membranes based on hydrocarbon polymers. Due to their chemical stability, high degree of proton-conductivity, and remarkable mechanical properties, perfluorinated polymer electrolytes such as Nafion ${ }^{\circledR}$, Aciplex ${ }^{\circledR}$, Flemion ${ }^{\circledR}$, and Dow membranes are some of the most promising electrolyte membranes for polymer electrolyte fuel cells. A number of reviews on the synthesis, electrochemical properties, and fuel cell applications of perfluorinated polymer electrolytes have also appeared. While perfluorinated polymer electrolytes have satisfactory properties for a successful fuel cell electrolyte membrane, the major drawbacks to large-scale commercial use involve high cost and low proton-conductivities at high temperatures and low humidities. Presently, one of the most promising ways to obtain high-performance proton-conducting polymer electrolyte membranes is the use of hydrocarbon polymers for the polymer backbone. The present paper attempted to summarize the synthesis, chemical and electrochemical properties, and fuel cell application of new proton conducting polymer electrolytes based on hydrocarbon polymers that have been made during the past decade.

Key words : proton / polymer electrolyte fuel cell / hydrocarbon polymer $/$ high temperature $/$ membrane

\section{1.はじめに}

近年の地球環境，エネルギー枯渴問題を背景に, 燃料電池に対する期待が益々増えつつある。とり わけ高分子電解質形燃料電池 (PEFC) に対する 期待は大きく, 自動車搭載用然料電池からマイク 口燃料電池まで幅広い分野で実用化が望まれてい る.しかしながら，ここ数年多くの実用化研究が 行われているが，実用化を加速するような新たな 研究上のブレークスルーは見出されていない. 実
用化に対する課題は, 触媒, 七ル構成, システム 管理などいくつか上げられるが，画期的な触媒の 開発とともに重要な課題は新規な高分子電解質膜 の開発と考えられている。特に低コストな膜, $100^{\circ} \mathrm{C}$ 以上の高温で高いプロトン伝導性を示す膜, メタノールなどの燃料透過性の低い膜の開発はナ フィオンに代表されるフッ素系電解質膜だけでは 実現しがたく，実用化または次世代PEFCに不可 避な技術課題と言える1 6).

このような背景をもとに，フッ素系電解質膜で 

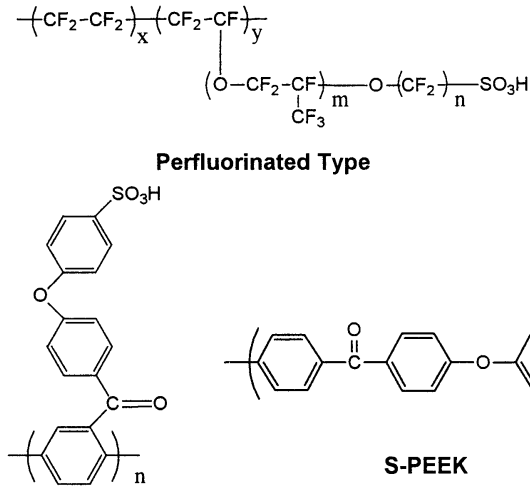

Perfluorinated Type

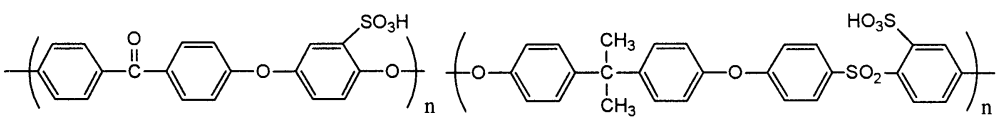

S-PEEK

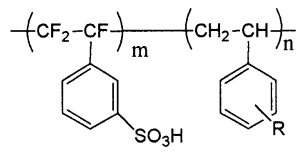

Semifluorinated Type

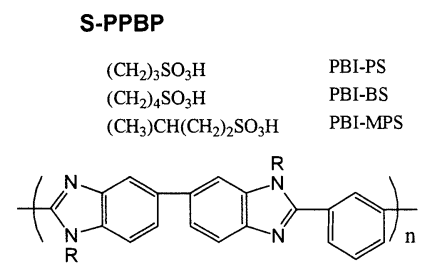

PBI-AS

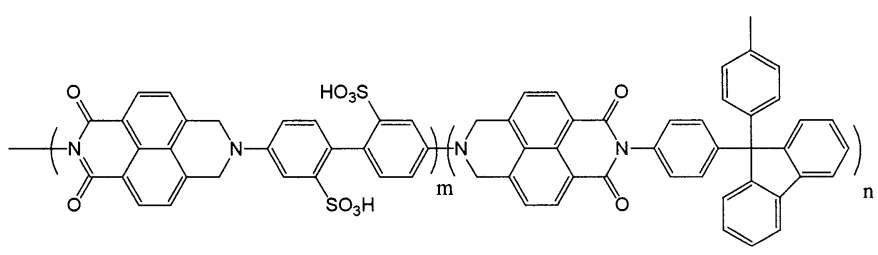

S-PI

Hydrocarbon Type

Fig. 1 Chemical structure of polymer electrolyte membranes.

は得られない特性を有する新規な高分子電解質膜 の開発を目的に, Fig. 1に示すような多くの高分子 電解質膜の研究が行われている，主鎖骨格または 側鎖にフッ化物を有する部分フッ素化電解質膜, PTFEなどの多孔質膜に高分子電解質を充填した八 イブリッド膜, ゾルゲル法などによりシリカと高 分子電解質をハイブリッドした膜などがあるが, 最近エンジニアリングプラスチックを基本骨格に した炭化水素系高分子による新規電解質膜の研究 事例が多くなっている。 そ水は炭化水素系電解質 膜が比較的安価な汎用樹脂やモノマーから容易に 合成できることが大きな理由であるが，高いガラ 又転移温度を有する材料や燃料透過性の低い材料 が得られるなどフッ素系電解質膜で得にくい特徵 を有していることも，これらの材料の魅力となっ ている.

では，なぜ炭化水素系電解質膜は未だ実用化し ないのであろうか.一つはフッ素系電解質膜の研 究に比べて, 研究期間と研究者数が圧倒的に少な いために, 実用化に必要な充分な基礎データが得 られていないためである。もう一つは，骨格が炭
化水素鎖であるために予想される以下の問題点を 充分に解決していないためである。

1 ) フッ素系電解質膜に比べ熱的, 化学的安定性 が低い。

2 ) 極性基の酸強度が低いために高プロトン伝導 性が得にくい。

3 ) 機械的強度が低い.

4 ) フッ素系電解質に見られるミクロ相分離構造 がないために，水の利用効率が低い.

前者の基礎デー夕の蓄積や炭化水素系電解質膜 に適したMEA作製条件や燃料電池運転条件などの システム設計は, あと 5 年程度の期間で充分にな されるものと予想される. 我々は後者の炭化水素 系電解質膜に課されている上述の問題点を解決す るために, 一連の炭化水素系電解質膜を開発した. その中で，まだ一部ではあるが問題の解決方法と 実用化のための方法論を構築してきた. 本報では, 主に上記項目 1 と 2 いいて数件の実例をもとに炭 化水素系電解質膜の問題点と実用化のための方法 論について報告する. 


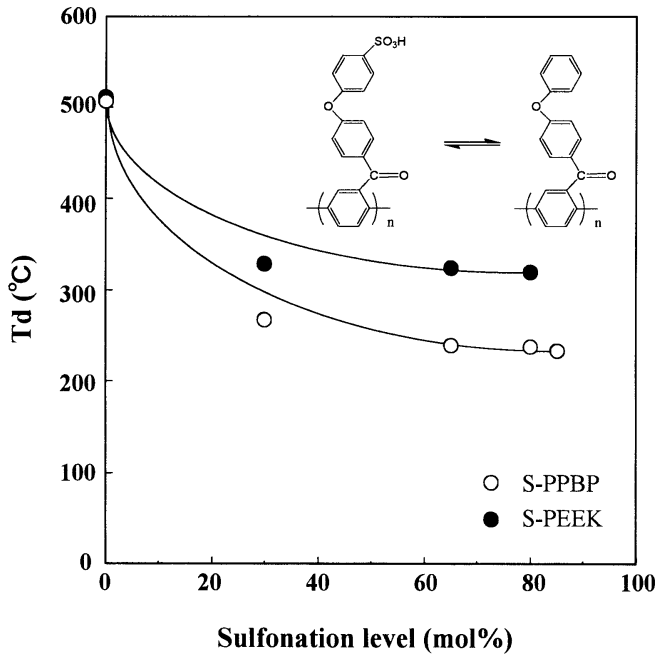

Fig. 2 Thermal decomposition temperature of S-PPBP and SPEEK.

\section{2. 炭化水素系電解質膜の熱的, 化学的安 定性}

高分子電解質膜の熱的, 化学的安定性がPEFC の信頼性と耐久性を決定するため，おのずと高い 安定性が求められている。しかしながら，このス ペックは意外に曖昧なもので，ほとんど定量性の ないものである。これはPEFCの長期耐久性と高 分子電解質膜の熱的，化学的安定性の相関が明ら かにされていないためであり，現在は暗黙のうち にフッ素系電解質膜の安定性を標準とする傾向に ある。また，安定性の評価法も実際には確立され ておらず，多くの場合，熱的安定性にはTG-DTA に代表される熱分解試験が用いられ，化学的安定 性はFenton試薬による耐性試験が用いられている。 これらの評価方法の信頼性には疑問が残される が，ここでも一般的な手法ではある上記の測定を もとに報告する。なお，一口にTG-DTA測定や Fenton試験と言っても細かい条件は文献や報告に よりかなり異なるので注意する必要がある.

テフロンのようにフルオロアルキル鎖を有する フッ素系高分子は, 熱的, 化学的安定性に優れて いる，その特性は，フルオロアルキル鎖を主鎖骨 格にもつナフィオン類にも受け継がれており，高

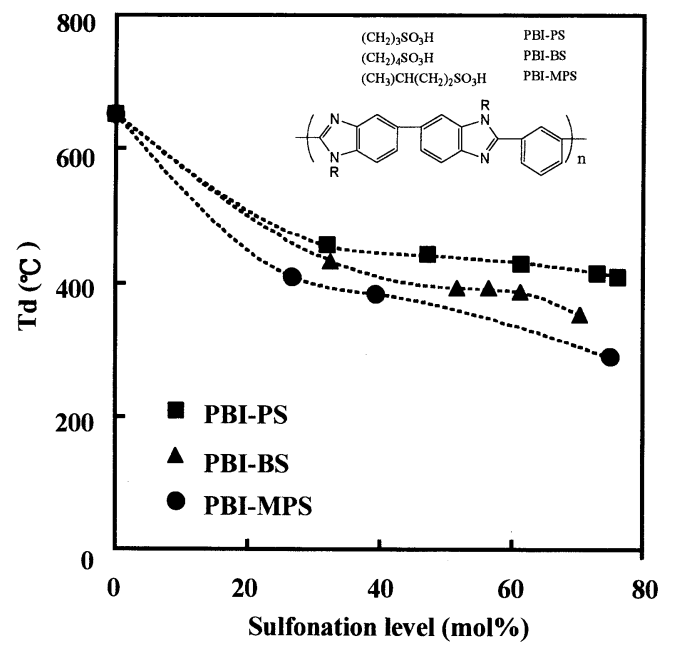

Fig. 3 Thermal decomposition temperature of PBI-AS.

い耐久性を有している。一方，芳香族高分子をも とにした炭化水素系電解質では，もとになるエン ジニアリングプラスチック自体の熱的安定性は高 く, $500^{\circ} \mathrm{C}$ 以上の熱安定性を示すものもある。し かし，高プロトン伝導性をもたせるためにスルホ ン酸基のような極性基を導入するとその熱安定性 は低下する．Fig. 2に例としてポリ（4-フェノキシ ベンゾイル-1,4-フェニレン）（PPBP）をスルホン 化（S-PPBP）したときのスルホン化率と熱分解開 始温度（Td）の関係を示した。スルホン化率の増 加に伴い熱分解開始温度は低下し，スルホン化率

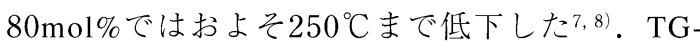
TDA測定後の試料のFT-IR と元素分析の結果, こ の分解反応は脱スルホン化によるものであること が明らかになった。同様にポリエーテルエーテル ケトン (PEEK) やポリエーテルスルホン (PES) をスルホン化したところ（S-PEEK, S-PES), 同 じようにスルホン化による熱的安定性の低下が確 認された。このように多くのエンジニアリングプ ラスチックの場合, 充分なプロトン伝導性を与え る程度にスルホン化すると，その熱分解開始温度 は $200-350^{\circ} \mathrm{C}$ 程度になる。燃料電池の作動温度を 考えると上述の值でも充分な耐熱性と思われる が，熱的安定性を向上させる手法がいくつか試み られている。 


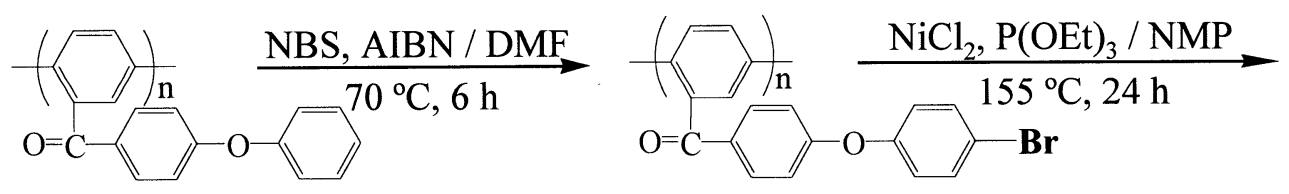

PPBP

PPBP-Br

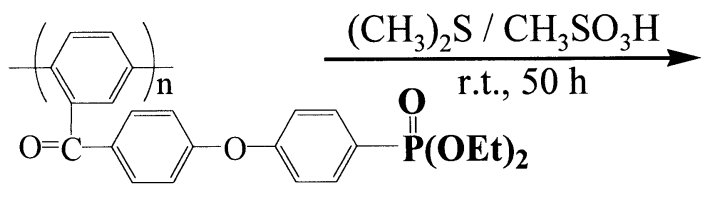

EP-PPBP

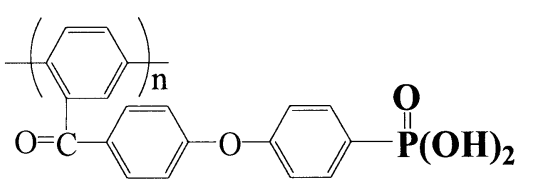

P-PPBP

Fig. 4 Synthetic route of P-PPBP.

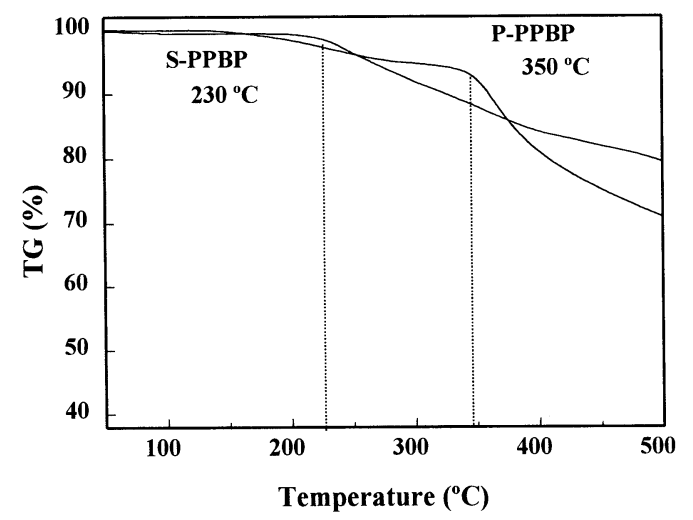

Fig. 5 Thermal decomposition temperature of P-PPBP.

芳香族スルホン酸を酸性水溶液で $100-175^{\circ} \mathrm{C}$ に 加熱すると, 芳香族スルホン酸は芳香族炭化水素 に変化する。これはスルホン化反応の化学平衡が 逆方向に移動するからであり，一般に脱スルホン 化反応と言われる。したがって，スルホン化反応 の逆条件である薄い酸や加熱水蒸気を通じたりす ると, 容易にこの脱スルホン化反応が起こる。つ まりは上述の条件は燃料電池内の高分子電解質膜 がさらされている雲囲気に類似しているので，ス ルホン酸が直接芳香族環に結合している炭化水素 系電解質膜ではPEFCの電解質膜として使用して いると容易に脱スルホン化反応が起き, 燃料電池 の耐久性に致命的な影響を与えることが予想され る.この問題を解決するために, 我々はFig. 1に示
すように，脱スルホン化反応が起こりにくいアル キルスルホン酸基を極性基としてもつ一連の高分 子電解質膜を開発した ${ }^{9,10)}$. Fig. 3に示すように, いずれのアルキルスルホン化ベンズイミダゾール も $400^{\circ} \mathrm{C}$ 程度の耐熱性を示し，脂肪族鎖を介して スルホン酸基を導入することで高分子電解質膜の 熱的安定性を向上させうることを見出した。同様 に，脱スルホン化反応を抑制するためにスルホン 酸基が結合している芳香族環に電子吸引基を導入 する試みも行われている11).

極性基の種類を変えることにより炭化水素系電 解質膜の熱的安定性を向上させることも可能であ る.Fig. 4に示した合成手法により上記のPPBPに 高分子反応でホスホン酸基を導入した高分子電解 質膜（P-PPBP）を合成することができる. Fig. 5 に示すように，ホスホン酸基はスルホン酸基に見 られるような $200-300^{\circ} \mathrm{C}$ 程度の加熱による極性基 の脱離反応が観察されず，水酸基間の縮合反応と 思われる水の脱離が $350^{\circ} \mathrm{C}$ 近傍に観察される。こ のように，スルホン酸基をホスホン酸基に変える ことにより電解質膜の耐熱性を $100^{\circ} \mathrm{C}$ 程度向上す ることができる、現段階では, ホスホン酸基の弱 酸性により導電率は $10^{-4} \mathrm{~S} / \mathrm{cm}$ とあまり高くはない が, イオン交換容量を増加させ, スルホン酸基な どの強酸性基を混在することにより導電率の飛躍 的な向上が期待できる.

一方, 化学的な安定性は前述のようにPEFCに 

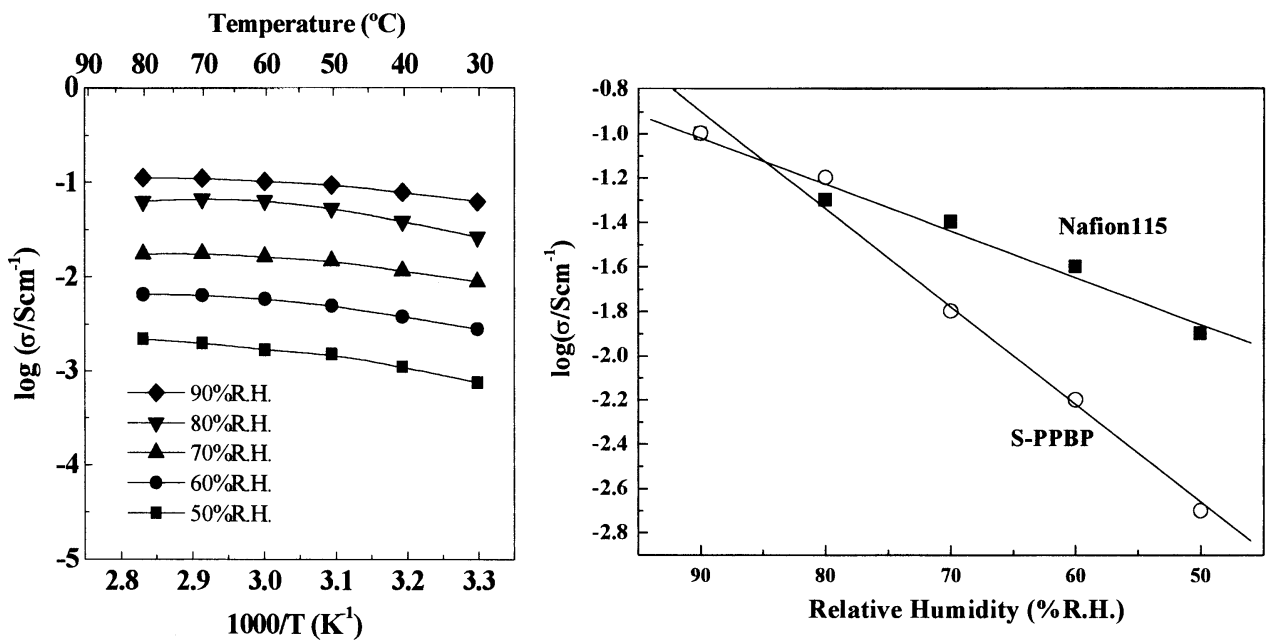

Fig. 6 Temperature (left) and relative humidity (right) dependence of proton conductivity for S-PPBP and Nafion 115.

よる長期信頼性試験の代用としてFenton試験が多 く用いられている。我々は, $2 \mathrm{ppm} の \mathrm{Fe}^{2+}$ 含む $3 \%$ 過酸化水素水溶液を $100^{\circ} \mathrm{C}$ に加熱し, これに高 分子電解質膜を浸漬し，浸漬前後の重量変化およ びイオン交換容量の変化から膜の化学的安定性を 調べた。単純な構造であるS-PPBP膜は，1時間以 内に膜の分解が起こり急激な重量減少が観察さ れ，ラジカル耐性とも言える化学的安定性があま り高くないことが予想される. 最も高い熱的安定 性を示したアルキルスルホン化ポリベンズイミダ ゾール類は，その耐熱性を反映して1時間程度で はほとんど重量減少が観測されず，数時間後に 数\%の重量減少が見られた。したがって，熱的， 化学的分解挙動が脱スルホン化反応のように類似 の原因による場合，熱的安定性と化学的安定性に はある程度相関関係が見い出せる。一方，ホスホ ン酸基を有するP-PPBPは, Fenton試薬に対して高 い耐性を示し, 数時間後でも膜の重量減少は観察 されない.これはリン酸基の場合にも見られた現 象であり，今後その原因を明らかにする予定であ る.

このように炭化水素系電解質膜の最大の弱点と 考えられている熱的, 化学的安定性に関して検討 したところ, 熱的安定性ではフッ素系電解質膜を
超える特性を有する材料が得られることがわかっ た。また，化学的安定性はFenton試験から考察す ると, いずれの炭化水素系電解質膜もフッ素系電 解質膜を超える化学的安定性を示すことはない. しかしながら, アルキルスルホン化やホスホン酸 基などの導入によりある程度の化学的安定性の向 上が期待できるので, 今後は長期燃料電池試験を 行い実用に近いレベルの化学的安定性について明 らかにする必要がある。

\section{3. 極性基の酸性度とプロトン伝導性}

フッ素系電解質膜では，フルオロアルキル側鎖 による電子吸引効果により側鎖末端に結合してい るスルホン酸は, 炭化水素系スルホン酸と比較す るとより強い酸として機能する。したがって,イ オン交換容量が同じ高分子電解質膜では, フッ素 系電解質膜の方が高いプロトン伝導性を発現する と考えられ, 炭化水素系電解質膜ではフッ素系電 解質膜より高いイオン交換容量の膜を設計する必 要が生じる。

フッ素系電解質膜のイオン交換容量は, 隔膜と しての機械的特性を維持するためにほぼ一定であ り, 0.9-1.1 meq/g (EW值1100-900) 程度の電解 
質膜が多く用いられている。短側鎖型のDow膜は 他のフッ素系電解質膜よりイオン交換容量 (1.25 $\mathrm{meq} / \mathrm{g}, \mathrm{EW}$ 值 $=800 ）$ が高く，これがDow膜を用い たPEFCの性能向上に結びついている.しかしな がら，環化問題や機械的強度の問題などにより現 在まで実用化に至っていない12)。比較的高い機械 的強度と高いイオン交換容量を有する電解質膜と して, BAM3G膜のような部分フッ素化電解質膜 の開発も試みられている13)。これらに対して，炭 化水素系電解質膜はフッ素原子を使わずに機械的 強度に優れた電解質膜を得ることができるので, 比較的高いイオン交換容量を有する膜を開発する ことが可能である。また，極性基であるスルホン 酸基を高分子反応により後から導入することが可 能であるため, 容易にイオン交換容量を制御する ことができる。例えば，S-PPBPでは $1-2 \mathrm{meq} / \mathrm{g}$ 程 度（EW值 $=1000-500 ）$ のイオン交換容量を有す る電解質膜が容易に得られる。その含水率および プロトン伝導率は, イオン交換容量に比例して増 大し, Fig. 6 (左) に示すように $2 \mathrm{meq} / \mathrm{g}$ 程度のイ オン交換容量を有するS-PPBP膜では， $10^{-1} \mathrm{~S} / \mathrm{cm}$ オ ーダーのプロトン伝導性を示す。この值はフッ素 系電解質膜の導電率と同等か, それ以上の值であ り，機械的強度を損なわずにイオン交換容量を制 御できれば，極性基の酸強度によらず実用に充分 なプロトン伝導性を電解質膜に付与することがで きる。つまり，炭化水素系電解質のように電解質 膜の機械的特性を左右する主鎖骨格を様々に变え ることが可能であれば，プロトン伝導性に関して は充分な特性が得られることになる。

しかしながら，炭化水素系電解質に扔けるイオ ン交換容量の増加による高プロトン伝導性の確保 は，フッ素系電解質に見られない一つの大きな問 題を抱えている. Fig. 6 (右) において，ナフィオ ン115膜とS-PPBP膜の導電率の湿度依存性を比較 すると, 圧倒的にナフィオン 115 膜の方がプロト ン伝導率の湿度依存性が小さいことがわかる。つ まり，電解質膜にとって充分な加湿条件である高 湿度下では, ナフィオン115膜とS-PPBP膜とでは 導電率にほとんど差がないが, 低湿度領域ではSPPBP膜の方が全般的に導電率が低下していること
がわかる。これは，それぞれの電解質膜のミクロ 構造の違いによるものと解釈される。よく知られ ているようにフッ素系電解質膜では, 主鎖の疎水 性，側鎖の親水性に起因するミクロ相分離構造を 形成するために，水のクラスターチャネル構造が 存在する。この少ない水分子を利用した水のクラ スター構造が存在するために，水の利用効率が高 く，低湿度下でも高いプロトン伝導性を維持する ことができる。当然，前項に示したように酸強度 の高い極性基を有していることも，低湿度下にお ける高プロトン伝導性に寄与している。これに対 して, 炭化水素系電解質膜ではフッ素系電解質膜 のような明瞭な疎水-親水ドメインによる相分離構 造が存在しないために，少ない水分子を凝集させ てプロトン伝導経路を形成することが困難になっ ている.

この炭化水素系電解質膜における久点は, 低加 湿度運転や起動時間の短縮には不利に作用するこ とが予想されるので, 今後何らかの手法で改善す ることが望まれる。部分フッ素化した官能基など 疎水性の強いユニットを導入することで，この問 題点をかなり解決することが可能であるので, 高 分子電解質の 1 次構造を含めた，より高次な構造 制御が今後必要になる。

\section{4. おわりに}

本報告では炭化水素系電解質膜がもっている潜 在的な欠点について解説し, 我々の研究結果をも とにその解決方法の例を示した。 上述の手法のみ ならず最近多くの試みがなされ，数多くの新規炭 化水素系電解質膜が開発されてきている. 炭化水 素系電解質膜においては, 現在PEFCの初期特性 評価や簡単な耐久試験などが行われる段階に来て いるので，今後の飛躍的発展を期待したい。また， 個人的にはフッ素系電解質膜と比較して明らかに なる欠点を改善する保守的な研究に留まらずに, 炭化水素系電解質膜独自の特性を活かした新しい 展開にも多くの力を集約したい. 
20 陸川：炭化水素系高分子電解質膜の可能性と問題点

\section{謝 辞}

本研究は, 文部科学省科学研究費補助金特定領 域研究, 新エネルギー・産業技術総合開発機構の 委託研究, ならびに (財) 熱・電気エネルギー技 術財団の助成によって行っています.

\section{文 献}

1) Rikukawa M, Sanui K: Prog. Polym. Sci., 25 1463-1502 (2000)

2) 陸川政弘:「固体高分子型燃料電池用イオン交換膜 の開発」,pp.89-120, シーエムシー社 (2000)

3) 陸川政弘: 固体高分子型燃料電池, pp.25-35, 技術情報 協会 (2001)

4) 川原光泰, 陸川政弘: 材料の科学と工学, 39 84-88 (2002)
5) 本間 格: 膜, 27 118-123 (2002)

6) 宮武健治, 渡辺政廣: 膜, 27 131-138 (2002)

7) Ogata N, Rikukawa M: US Patent 5403675 (1995)

8) Kobayashi T, Rikukawa M, Sanui K, Ogata N: Solid State Ionics, 106 219-225 (1998)

9) Kawahara M, Rikukawa M, Sanui K: Polym. Adv. Technol., 11 544-547 (2000)

10) Kawahara M, Rikukawa M, Sanui K, Ogata N: Solid State Ionics, 136-137, 1193-1196 (2000)

11) Miyatake K, Iyotani H, Yamamoto K, Tsuchida E: Macromolecules, 29 6969-6971 (1996)

12) 木本協司: 「固体高分子型燃料電池用イオン交換膜 の開発」,pp.19-58, シーエムシー社 (2000)

13) 富家和男:「固体高分子型燃料電池用イオン交換膜 の開発」,pp.61-86, シーエムシー社 (2000) (受付 2002年9月22日 掲載決定 11月15日) 